CARPATHIAN JOURNAL OF FOOD SCIENCE AND TECHNOLOGY

journalhomepage:http://chimie-biologie.ubm.ro/carpathian_journal/index.html

\title{
SUPERIORITY OF GERMINATED OVER RAW SAMPLE IN PROXIMATE COMPOSITION AND OVER BOTH RAW AND FERMENTED IN MINERALS OF ZEA MAYS L. DK 818
}

\begin{tabular}{|c|c|}
\hline \multicolumn{2}{|c|}{$\begin{array}{l}\text { IDepartment of Chemistry, Ekiti State University, Ado-Ekiti, P.M.B. 5363, Ekiti State, Nigeria } \\
{ }^{2} \text { Department of Chemistry, Federal University Dutse, P.M.B. 7156, Jigawa State, Nigeria } \\
{ }^{3} \text { Department of Chemistry, Faculty of Science, University of Lagos, Nigeria } \\
\bigotimes_{\text {adeyeyeilesanmi2012@gmail.com }} \\
\text { oi.org/10.34302/crpjfst/2021.13.4.7 }\end{array}$} \\
\hline $\begin{array}{l}\text { Article history: } \\
\text { Received: } \\
\quad 24 \text { September } 2020 \\
\text { Accepted: } \\
\quad 17 \text { September } 2021 \\
\text { Keywords: } \\
\text { Zea mays, } \\
\text { Processed and unprocessed } \\
\text { grains, } \\
\text { proximate and mineral levels. }\end{array}$ & 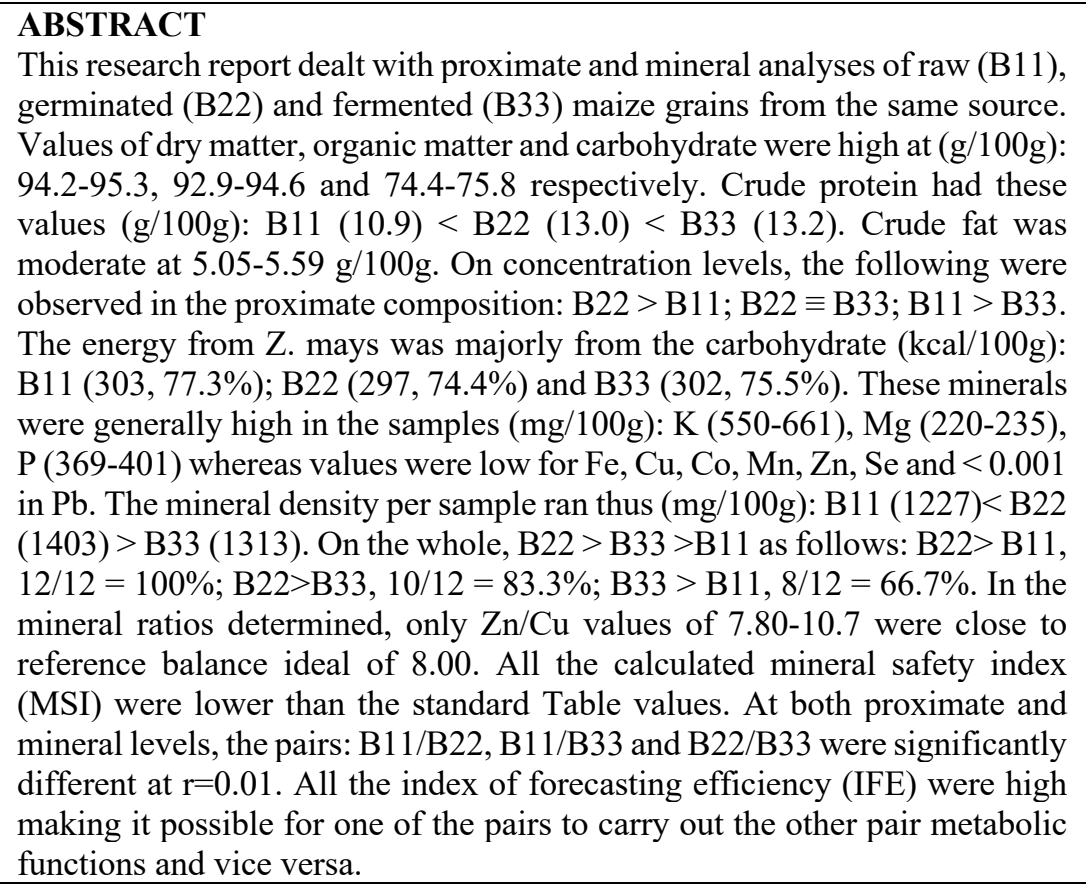 \\
\hline
\end{tabular}

\section{Introduction}

The word "maize" derives from the Spanish form of the indigenous Taino word for the plant mahiz (Maize, 2012). It is known by other names around the world. Seed of maize contains endosperm which is a food storage organ and consists primarily of starch which is digested into sugar when germination occurs and growth begins. Maize may be divided into vaious groups differing in endosperm character of the seeds. These groups or types are (Obi,1991):
-Flour corn: Zea mays var. amylacea Sturt. -Popcorn: Zea mays var. everta Sturt.

-Dent corn: Zea mays var. indentata Sturt.

-Flint corn: Zea mays var. indurate Sturt.

-Sweet corn: Zea mays var. saccharata Sturt and Zea mays var. rugosa.

-Waxy corn: Zea mays var. ceratina Kulesh.

-Amylomaize: Zea mays

-Pod corn: Zea mays var. tunicate Sturt Larranaga ex A. St. Hil.

-Striped maize: Zea mays var. japonica 
This is an artificial classification that is not indicative of natural relationships; however, these subspecies are sometimes classified as various subspecies related to the amount of starch each has. Dent and Flint account for the bulk of world production; pop, sweet and flour corn are used almost entirely for human consumption; pod and waxy are not important as food stuffs, however, waxy maize is used industrially in the United State of America (Obi, 1991).

\subsection{Maize scientific classification}

Kingdom (Plantae), Clade (Tracheophytes), Clade (Angiosperms), Clade (Monocots), Clade (Commelinids), Order (Poales), Family (Poaceae), Genus (Zea), Species (Z. mays), Binomial name (Zea mays L.).

Maize is widely cultivated throughout the world and a greater weight is produced each year than any other grain (International Grains Council, 2013). In 2018, total world production was 1.15 billion tonnes, led by the USA with $34.2 \%$ (392.5) of the total. China produced $22.4 \%$ (257.3) of the global total (FAOSTAT, 2020). Actual world total was 1147.6 (millions of tonnes). Nigeria was number 14 world producer (10.2 million tonnes) which is about $0.889 \%$. Maize has a very high yield of energy more than wheat and rice. Maize of about $93 \%$ extraction has an average yield of 5.4 million calories per hectare, thus ranking wheat $(85 \%$ extraction) and rice (70\% extraction) which gave average yield of 3.2 and 4.3 million calories per hectare, respectively (FAO, 1968). In Africa, maize consumption accounts for about $64 \%$ of the total daily calorie intake of the rural dwellers especially during the hunger "period". In Southern Nigeria, maize has been used primarily as human food (Obi, 1991). It is eaten as whole grain when boiled or roasted and used in its prepared form as pap (ogi) or eko (Agidi) which is an extracted starch meal obtained after a prolonged soaking of maize. Maize consumption in the Western States of Nigeria varies from 2.6-2.8kg per person per week (Agboola, 1979). In Nigeria, Anasonwu-Bello (Anazonwu - Bello, 1986) published over forty recipes from maize to encourage maximum use of maize as food-crop and to give it a new outlook. Of these recipes "Ogi" (Yoruba) or "Agidi" (Igbo) and "Akamu" (Igbo) are corn diets eaten by almost all the ethnic groups of Nigeria. Obi (1991) had further elaborated the maize recipes of other countries. In Ghana, "Kenkey" is the principal corn diet of the people. In Benin Republic (corn fritters); in Cameroon (Koga); in Malawi (roasted and parched maize); in Kenya ("Posho" or Gruel", "Ugali" and "Gbenga"); in the Republic of South Africa (Mahewa or Magou, a non-alcoholic drink, is made from sorghum which is supplemented with corn); in Central and South America, "Tortilla" as "Echilada" or "Taco" or "Tamele" are corn diets of the people. From Central and South America, other food preparations of corn are "Atole", "Penolillo", "Chicheme", "Colada" and "Chicha dulee". In Nigeria, akamu or ogi has a consistency similar to that of American pudding (Kulp, 2000). Ogi/Akamu in Nigeria is generally accompanied with moinmoin, a bean pudding of akara which is a bean cake.

Maize grains have long been shown to be of poor quality protein and consequently of poor nutritive value due to high levels of zein. The protein fraction of maize (zein) has insignificant amounts of Lys and Trp (Jose, 1966). The deficiency of these amino acids has resulted in negative nitrogen balance and poor growth of animals and humans fed on unbalanced maize meals. The economic importance of developing a good quality protein maize is immense. It will go a long way in helping to solve human nutritional problems especially kwashiorkor among babies weaned akamu or ogi diet.

The major aim of this research was to see if processing the maize grains would improve their nutritional quality. To this end, similar grains of maize (Zea mays L. Dk 818) were subjected to fermentation and sprouting, dried, pulverized and analysed for proximate and mineral contents. Data results were discussed comparatively and conclusions drawn.

\section{Materials and methods}

\subsection{Collection of samples}

Samples of maize grains were collected from the Department of Crop, Soil and Wildlife, Ekiti 
State University, Ado-Ekiti, Nigeria. About $1.5 \mathrm{~kg}$ of the grains were used for the experiments. After removing stones, damaged grains, manually, the maize grains were divided into three equal parts for use as raw, steeped (fermented) and germinated (sprouted) maize samples. Raw samples were labeled as B11 and no further treatment after cleaning. It was however dried to constant weight.

\subsection{Sample treatment}

For steeping, $0.50 \mathrm{~kg}$ grains were placed in a plastic container, covered with distilled water and left in the laboratory at ambient temperature $\left(30.9^{\circ} \mathrm{C}\right)$ at $0.41 \mathrm{Im}^{2} / \mathrm{ft}$ light intensity. After four days, grains were washed with distilled water, dried in sun to constant weight and stored in covered plastic container; this was labeled B33 (Fig-1). For germination of samples, $0.5 \mathrm{~kg}$ were soaked in water at room temperature for $24 \mathrm{~h}$; then spread on a damp fabric, protected from direct sunlight, for approximately $48 \mathrm{~h}$ until $5.04 \mathrm{~cm}$ long sprouts developed. Germinated grains were dried in sun for three days until constant weight; sprouts were manually removed and desprouted grains were stored in plastic container (FAO, 1976); this was labeled sample B22 (Fig-1). Each sample was homogenized, sieved using 200 mesh size and kept in the refrigerator $\left(2.8^{\circ} \mathrm{C}\right)$. Triplicates of raw, steeped and germinated grains were used for the proximate and mineral compositions.

\subsection{Proximate composition determination}

Moisture content was estimated gravimetrically by drying the flours at $100^{\circ} \mathrm{C}$ in ventilated oven to express moisture in $\mathrm{g} / 100 \mathrm{~g}$. Crude protein $(\mathrm{N} \times 6.25)$ of the flours was evaluated following the method of micro-Kjeldahl (Pearson, 1976). Crude fat was extracted with chloroform/methanol $(2: 1 \mathrm{v} / \mathrm{v})$ mixture using Soxhlet extraction apparatus (AOAC, 2006). Carbohydrate was calculated by difference.

Carbohydrates $(\mathrm{g} / 100 \mathrm{~g})=[$ Protein $(\mathrm{g} / 100 \mathrm{~g})+$ Lipids $(\mathrm{g} / 100 \mathrm{~g})+$ Fibre $(\mathrm{g} / 100 \mathrm{~g})+$ Ash $(\mathrm{g} / 100 \mathrm{~g})+$ Moisture $(\mathrm{g} / 100 \mathrm{~g})]$
Gross energy ( $\mathrm{kcal} / \mathrm{kJ} / 100 \mathrm{~g}$ ) was calculated using Atwater factors (Muller and Tobin, 1980).

Gross energy $(\mathrm{kcal} / 100 \mathrm{~g})=($ Protein $\times 4)+($ Lipid $\times 9)+($ Carbohydrate $\times 4)$

Gross energy $(\mathrm{kJ} / 100 \mathrm{~g})=($ Protein $\times 17)+($ Lipid $\times$ $37)+($ Carbohydrate $\times 17$

Utilizable energy due to protein (\%): UEDP $\%=$ $\%$ protein energy in gross energy $\times 60 \%$

Energy requirement for infants per day: calculation

$=100 /$ Total energy value $\times 740 \mathrm{kcal}$

Water required for complete protein metabolism for each sample: $\mathrm{X} \times 3=\mathrm{y} ; 3.5 \times \mathrm{X}=\mathrm{Z}$; Z-Y= water required

where $3=1$ calorie of protein requires $3.0 \mathrm{ml}$ of water for excretion of the urea and sulphate formed from it; $\mathrm{X}=$ protein energy in $\mathrm{kcal} / 100 \mathrm{~g} ; 3.5=$ water deficit $(350 / 100=3.5)$.

Conversion of lipid to total fatty acid (TFA): Crude fat $\times 0.72=$ TFA (Greenfield H. \& Southgate, 2003)

\subsection{Mineral analysis}

Minerals were determined using the solutions obtained by ashing the samples at $550^{\circ} \mathrm{C}$ and dissolving it in $10 \% \mathrm{HCl}$ and $(25 \mathrm{ml})$ and $5 \%$ lanthanum chloride $(2 \mathrm{ml})$, boiling, filtering and making up to standard volume with deionized water. Phosphorus was evaluated colorimetrically using a Spectronic 20 (GallenKamp, London, UK) instrument with $\mathrm{KH}_{2} \mathrm{PO}_{4}$ as the standard (AOAC, 2006). $\mathrm{Na}$ and $\mathrm{K}$ were determined by flame photometry, Model 405 (Corning, Halstead Essex, $\mathrm{UK}$ ) using $\mathrm{NaCl}$ and $\mathrm{KCl}$ to prepare standards. All other elements ( $\mathrm{Ca}, \mathrm{Mg}, \mathrm{Fe}, \mathrm{Zn}, \mathrm{Ni}, \mathrm{Co}, \mathrm{CU}, \mathrm{Pb}$ and $\mathrm{Se}$ ) were determined by atomic absorption spectrophotometry, Model 403 (perkin-Elmer, Norwalk, Connecticut, USA). All chemicals used were of analytical grade, and were products 
obtained from British Drug House (BDH, London, UK). Detection limits for the metals in aqueous solution had been determined just before the mineral analyses using the methods of Varian Techtron (Varian, 1975) giving the following values in $\mu \mathrm{g} / \mathrm{ml}$ : $\mathrm{Fe}(0.01), \mathrm{Cu}(0.002), \mathrm{Na}(0.002)$, $\mathrm{K}(0.005), \mathrm{Ca}$ (0.04), $\mathrm{Pb}(0.08), \mathrm{Mg}(0.002), \mathrm{Zn}$ (0.005), Mn (0.01), Co (0.05), Mn (0.01) and Se (0.15). The optimal analytical range was $0.1-0.5$ absorbance units with coefficients of variation from $0.9-2.2 \%$. From the mineral elements determined, further calculations were made.

\subsection{Mineral ratios}

Ratios of $\mathrm{Ca} / \mathrm{Mg}, \mathrm{Ca} / \mathrm{K}, \mathrm{Zn} / \mathrm{Cu}, \mathrm{Ca} / \mathrm{P}, \mathrm{Fe} / \mathrm{Cu}$, $\mathrm{Ca} / \mathrm{Pb}, \mathrm{Fe} / \mathrm{Pb}, \mathrm{Fe} / \mathrm{Co}, \mathrm{Na} / \mathrm{Mg}, \mathrm{K} / \mathrm{Co}, \mathrm{K} /[(\mathrm{Ca}+$ $\mathrm{Mg}$ )], $\mathrm{Na} / \mathrm{K}$ and $\mathrm{Zn} / \mathrm{Pb}$ (Hatcock, 1985; Watts, 2010; ARL, 2012) were calculated.

\section{Mineral safety index (MSI)}

The mineral safety index (MSI) (Hatcock, 1985) of $\mathrm{Fe}, \mathrm{Ca}, \mathrm{P}, \mathrm{Mg}, \mathrm{Zn}, \mathrm{Na}$ and $\mathrm{Se}$ were calculated using the formula:

MSI $=$ MSIs $/$ RAI $\times$ Research data result

where $\mathrm{MSI}=$ mineral safety index of Table (standard); RAI = recommended adult intake.

\subsection{Statistical analyses}

Both descriptive and inferential statistics were used to discuss the analytical results. The descriptive statistics used were mean, standard deviation (SD) and coefficient of variation percent $(\mathrm{CV} \%)$. For the inferential statiatics, Pearson's moment correlation coefficient $\left(\mathrm{r}_{\mathrm{xy}}\right)$ mode was used (Oloto, 2001). Further to the $r_{x y}$ calculation were the determination of variance $\left(r_{x y}^{2}\right)$, regression coefficient $\left(\mathrm{R}_{\mathrm{xy}}\right)$. Also determined were the coefficient of alienation $\left(\mathrm{C}_{\mathrm{A}}\right)$ and index of forecasting efficiency (IFE) (Chase, 1976). The level of significance of $r_{x y}$ was determined at a critical level of $r=0.01$.

$$
\begin{aligned}
\mathrm{C}_{\mathrm{A}} & =\sqrt{1-\left(\mathrm{r}_{\mathrm{xy}}\right)^{2}} \\
\mathrm{IFE} & =\left(1-\mathrm{C}_{\mathrm{A}}\right) 100
\end{aligned}
$$

\subsection{PubChem CID for mineral elements}

Mineral elements studied in this report were: Copper/Cu (PubChem CID: 23978); Iron/Fe (PubChem CID: 23925); Zinc/Zn (PubChem CID: 23994); Magnesium/Mg (PubChem CID: 5462224); Calcium/Ca (PubChem CID: 5460341); Cobalt/Co (PubChem CID: 104730); Manganese/Mn (PubChem CID: 23930); Sodium $/ \mathrm{Na}$ (PubChem CID: 5360545); Potassium $/ \mathrm{K}$ (PubChem CID: 5462222); Phosphorus/P (PubChem CID: 5462309); Selenium/Se (PubChem CID: 6326970); Lead/Pb (PubChem CID: 5352425). PbChem is a database of chemical molecules and their activities against biological assay. The system is maintained by the National Centre for Biotechnology Information (NCBI). A component of the National Library of Medicine, which is part of the United States National Institute of Health (NIH). Hence we can talk of PubChem Compound ID (CID) (PubChem and ACS, 2018).

\section{Results and discussions}

The proximate profiles of the maize samples were shown in Table 1. Total ash of 0.73-1.34 had mean value of $1.10 \pm 0.327 \mathrm{~g} / 100 \mathrm{~g}$ with highest CV\% of 29.7 showing the highest disparity of values in the three samples. Ash value reduced from raw maize (B11) down to $0.73 \mathrm{~g} / 100 \mathrm{~g}$ (B33) shown as follows in $\mathrm{g} / 100 \mathrm{~g}$ : $1.34(\mathrm{~B} 11)>1.24$ (B22) $>0.73$ (B33). The next highest $\mathrm{CV} \%$ came from crude fibre $(\mathrm{CV} \%=18.5)$ with low levels of fibre having values of $(\mathrm{g} / 100 \mathrm{~g}): 1.07(\mathrm{~B} 11) \equiv 1.07$ $(B 22)>0.76$ (B33). Dry matter $(94.2-95.3 \mathrm{~g} / 100 \mathrm{~g})$ with mean of $94.9 \pm 0.635, \mathrm{CV} \%$ (0.669); organic matter $(92.9-94.6 \mathrm{~g} / 100 \mathrm{~g})$, mean of $93.9 \pm 0.874$ and CV\% (0.931) had the highest concentration values but least variations of $0.669-0.931 \%$. The carbohydrate was also high at $74.4-75.8 \mathrm{~g} / 100 \mathrm{~g}$, mean of $75.3 \pm 0.757 \mathrm{~g} / 100 \mathrm{~g}$ and $\mathrm{CV} \%$ of 1.01 . The protein value was relatively low in each sample with values of $10.9-13.2 \mathrm{~g} / 100 \mathrm{~g}$, mean of $12.4 \pm$ 1.27 and $\mathrm{CV} \%$ of 10.3 . The crude fat was low at values range of $5.05-5.06 \mathrm{~g} / 100 \mathrm{~g}$, mean of $5.23 \pm$ $0.309 \mathrm{~g} / 100 \mathrm{~g}$ with $\mathrm{CV} \%$ of 5.90 . Moisture was low and had $\mathrm{CV} \%$ of 12.2 . We recall that the samples underwent these treatments: raw (B11) had no 
special treatment, steeped (B33) had the seeds soaked in water for some days with probably high microbial activities likely due to the high enabling environment due to interplay of water, air and enzyme activities. These scenario might have happened in total ash where we observed $(\mathrm{g} / 100 \mathrm{~g})$ : $\mathrm{B} 11(1.34)>\mathrm{B} 22(1.24)>\mathrm{B} 33(0.73)$ respectively; crude fire: B11 (1.07) $\equiv \mathrm{B} 22$ (1.07) $>\mathrm{B} 33(0.76)$. However, treatment enhanced dry matter where $\mathrm{B} 11<\mathrm{B} 22 \equiv \mathrm{B} 33$, organic matter: $\mathrm{B} 11<\mathrm{B} 22<\mathrm{B} 33$ and protein: $\mathrm{B} 11<\mathrm{B} 22<\mathrm{B} 33$. No definite trend existed in moisture, carbohydrate and crude fat. The reduced moisture content in B22 and B33 was important as it would lead to lower microbial activities and therefore longer shelf life for the grains, it would reduce the bulk of the samples.
Protein was enhanced along the line of treatment as $\mathrm{B} 33>\mathrm{B} 22>\mathrm{B} 11$; this might be because microbial activities were more prolonged in B33 (steeped) processing, some chelated protein materials being released in the treatment process which was more in B33 than in B22 and none in B11. The fat content had the trend: $\mathrm{B} 11(5.06)<\mathrm{B} 22(5.59)>\mathrm{B} 33(5.05)$ that is $\mathrm{B} 22>\mathrm{B} 11$ by a value of $9.48 \%$ and $\mathrm{B} 22>$ $\mathrm{B} 33$ by a value of $9.66 \%$. The high increase in crude fat in B22 showed that some proximate components could have been used up by microorganisms to elevate the fat content level; also, it could have been possible for lipolytic microorganisms to have decomposed some of the fat in the steeped (B33) sample.

Table 1. Proximate composition of the maize samples: raw maize (B11), germinated maize (B22) and steeped maize (B33) at g/100g value on dry weight basis

\begin{tabular}{|l|l|l|l|l|l|l|}
\hline Parameter & B11 & B22 & B33 & Mean & SD & CV\% \\
\hline Total ash & 1.34 & 1.24 & 0.73 & 1.10 & 0.327 & 29.7 \\
\hline Moisture & 5.79 & 4.71 & 4.72 & 5.07 & 0.621 & 12.2 \\
\hline Crude fibre & 1.07 & 1.07 & 0.76 & 0.967 & 0.179 & 18.5 \\
\hline Carbohydrate & 75.8 & 74.4 & 75.6 & 75.3 & 0.757 & 1.01 \\
\hline Crude protein & 10.9 & 13.0 & 13.2 & 12.4 & 1.27 & 10.3 \\
\hline Crude fat & 5.06 & 5.59 & 5.05 & 5.23 & 0.309 & 5.90 \\
\hline Dry matter & 94.2 & 95.3 & 95.3 & 94.9 & 0.635 & 0.669 \\
\hline Organic mater & 92.9 & 94.1 & 94.6 & 93.9 & 0.874 & 0.931 \\
\hline
\end{tabular}

For example, a diversity of moulds such as Aspergillus spp., Penicillium spp. (Ogundiwin et al., 1991; Lefyedi, 2006) and bacteria such as Pseudomonas aeruginosa (Ilori et al., 1991; Ahmed, 2013) have been identified as microorganisms associated with sorghum grains and malt. This could be similar with maize grains. The lowest level of fibre $(0.76 \mathrm{~g} / 100 \mathrm{~g})$ in B33 could be due to highest level of protein in B33. The carbohydrate trend could not had been out of place as it is the first source of energy for organisms and since the process was raw $\rightarrow$ steeped $\rightarrow$ germinated; the diminishing level of carbohydrate would have followed that path.

Maize protein had been classified into five groups based on its solubility in various solvents (Obi, 1991). They are: (i) prolamines (soluble in
$70-80 \%$ ethanol). Prolamine is mainly Zein that accounts for about $50 \%$ of the total protein in the normal maize seed. Zein is deficient in Trp and Lys which are essential amino acids. Zein is located in the endosperm. It has an economic value in that it can be converted into a protein fibre called "vicara". Vicara is used in blends with wool for manufacturing socks, sweaters and swimming suits (Milner, 1954). Number (ii) the globulins (soluble in neutral salt solution, e.g. $5 \% \mathrm{NaCl}$ ); (iii) glutelins (soluble in sodium hydroxide, e.g. $0.2 \% \mathrm{NaOH}$ ); (iv) albumins (soluble in water, e.g. $50 \mathrm{ml}$ distilled water/g of defatted endosperm); (v) scleroproteins (insoluble in aqueous solvents), it amounts to about $4.3 \%$ of the endosperm protein of normal maize.

Profiled in Table 2 were the differences and the percentage differences in B11 - B22; B11 - B33 
and B22 - B33. The highest percentage difference was B11 - B33 $(+49.2 \%)$ in total ash followed by $\mathrm{B} 11-\mathrm{B} 33 \equiv \mathrm{B} 22-\mathrm{B} 33 \equiv 29.0 \%$ in crude fibre. The third major difference was in crude protein where B11-B33 $=-20.5 \%$; for the signs, positive $(+)$ meant the left hand value was higher than the right hand value and vice versa of the compared pair. On the whole we have this distribution: $\mathrm{B} 22>\mathrm{B} 11=$ $57.1 \% / 42.9 \%$; B22 $\equiv \mathrm{B} 33 \equiv 50.0 \% ; \mathrm{B} 11>\mathrm{B} 33=$ $62.5 \% / 37.5 \%$ in terms of concentration ratios.

Table 2. Proximate composition differences in the maize samples as B11-B22, B11-B33 and B22-B33

\begin{tabular}{|c|c|c|c|}
\hline Parameter & $\mathrm{B} 11-\mathrm{B} 22(\%)$ & $\mathrm{B} 11-\mathrm{B} 33(\%)$ & $\mathrm{B} 22-\mathrm{B} 33(\%)$ \\
\hline Total ash & $+0.100(+7.46)$ & $+0.610(+49.2)$ & $+0.510(+41.1)$ \\
\hline Moisture & $+1.08(+18.7)$ & $-0.010(-0.212)$ & $-0.010(-0.212)$ \\
\hline Crude fibre & $0.00(-)$ & $+0.310(+29.0)$ & $+0.310(+29.0)$ \\
\hline Carbohydrate & $+1.46(1.93)$ & $+0.24(+0.317)$ & $-1.22(-1.64)$ \\
\hline Crude protein & $-2.11(-19.3)$ & $-2.24(-20.5)$ & $-0.130(-0.997)$ \\
\hline Crude fat & $-0.530(-10.5)$ & $+0.010(+0.198)$ & $+0.540(+9.66)$ \\
\hline Dry matter & $-1.08(-1.15)$ & $+0.010(+0.010)$ & $+0.010(+0.010)$ \\
\hline Organic matter & $-1.18(-1.27)$ & $-0.500(-0.532)$ & $-0.500(-0.532)$ \\
\hline \multicolumn{4}{|c|}{$\begin{array}{l}\text { Summary: } \mathrm{B} 22>\mathrm{B} 11=57.1 \% / 42.9 \% ; \mathrm{B} 22 \equiv \mathrm{B} 33 \equiv 50.0 \% ; \mathrm{B} 11>\mathrm{B} 33=62.5 \% / 37.5 \% \text { in } \\
\text { terms of concentration ratios }\end{array}$} \\
\hline
\end{tabular}

The lipid distribution of the samples were depicted in Table 3. The crude fat was converted to total fatty acid (TFA) by multiplying the crude fat by 0.72 . The TFA or $\mathrm{g} / 100 \mathrm{~g} \mathrm{Ep}$ (edible portion) ranged between the $3.64-4.02 \mathrm{~g} / 100 \mathrm{gEp}$, mean of $3.77 \pm$ 0.219 and $\mathrm{CV} \%$ of $5.82 \%$; with TFA distributed as (g/100g EP): B11 $\equiv$ B33 $\equiv 3.64<$ B22 (4.02). Other lipids without TFA in the samples ranged from $1.41-1.57 \mathrm{~g} / 100 \mathrm{~g}$, mean of $1.47 \pm 0.09 \mathrm{~g} / 100 \mathrm{~g}$ and $\mathrm{CV} \%$ of 6.11 . The other lipids would be made up of sterols, phospholipids, etc. The percentage value for each TFA was $72.0 \%$ whereas other lipids percent was $28.0 \%$ in each sample. The values of constant percentage of 72 (TFA) and 28 (other lipids) was due to the constant conversion factor of 0.72 . The crude energy range was 45.5-50.3 $\mathrm{kcal} / 100 \mathrm{~g}$ and $187-207 \mathrm{~kJ} / 100 \mathrm{~g}$; for $\mathrm{g} / 100 \mathrm{gEp}$ (TFA), we have 32.7-32.8 kcal/100g and 135 $149 \mathrm{~kJ} / 100 \mathrm{~g}$; whereas other lipids had 12.7$14.1 \mathrm{kcal} / 100 \mathrm{~g}$ and $52.3-57.9 \mathrm{~kJ} / 100 \mathrm{~g}$. The total energy from TFA and other lipids $(\mathrm{kcal} / 100 \mathrm{~g})$ was $45.6(\mathrm{~B} 11)=45.5$ (crude fat); $50.3(\mathrm{~B} 22)=50.3$ (crude fat); 45.4 (B33) $=45.5$ (crude fat); each case giving virtually equivalent values. For both kcal and $\mathrm{kJ}$ energy percentages, each group recorded similar values: $\%$ TFA $=36.0$ for all and $\%$ other lipids $=14.0$ for all.

Table 3. Fat $(\mathrm{g} / 100 \mathrm{~g})$ distribution of the maize samples.

\begin{tabular}{|l|l|l|l|l|l|l|}
\hline Parameter & B11 & B22 & B33 & Mean & SD & CV\% \\
\hline Crude fat & 5.06 & 5.59 & 5.05 & 5.23 & 0.309 & 5.90 \\
\hline $\begin{array}{l}\text { Crude fat x 0.72 } \\
\text { (Total fatty acid) }\end{array}$ & 3.64 & 4.02 & 3.64 & 3.77 & 0.219 & 5.82 \\
\hline Other fats & 1.42 & 1.57 & 1.41 & 1.47 & 0.090 & 6.11 \\
\hline \%TFA & 72.0 & 72.0 & 72.0 & 72.0 & 0.00 & 0.00 \\
\hline$\%$ other fats & 28.0 & 28.0 & 28.0 & 28.0 & 0.00 & 0.00 \\
\hline $\begin{array}{l}\text { Energy (kcal) } \\
\text { crude fat (E) }\end{array}$ & 45.5 & 50.3 & 45.5 & 47.1 & 2.77 & 5.88 \\
\hline TFA (E) & 32.8 & 36.2 & 32.7 & 33.9 & 1.99 & 5.88 \\
\hline
\end{tabular}




\begin{tabular}{|l|l|l|l|l|l|l|}
\hline Other lipids (E) & 12.8 & 14.1 & 12.7 & 13.2 & 0.781 & 5.92 \\
\hline Total E (kcal) & 91.1 & 101 & 90.9 & 94.3 & 5.77 & 6.12 \\
\hline \% Crude fat (E) & 49.9 & 50.0 & 50.1 & 50.0 & 0.100 & 0.200 \\
\hline \%TFA (E) & 36.0 & 36.0 & 36.0 & 36.0 & 0.00 & 0.00 \\
\hline \% other fats (E) & 14.1 & 14.0 & 14.0 & 14.0 & 0.058 & 0.411 \\
\hline Energy (kJ) & & & & & & \\
\hline Crude fat (E) & 187 & 207 & 187 & 194 & 11.5 & 5.96 \\
\hline TFA (E) & 135 & 149 & 135 & 140 & 8.08 & 5.79 \\
\hline Other lipids (E) & 52.4 & 57.9 & 52.3 & 54.2 & 3.20 & 5.91 \\
\hline Total E (kJ) & 374 & 414 & 374 & 387 & 23.1 & 5.96 \\
\hline \% crude fat (E) & 49.9 & 50.0 & 50.0 & 50.0 & 0.058 & 0.116 \\
\hline \% TFA (E) & 36.1 & 36.0 & 36.1 & 36.1 & 0.058 & 0.160 \\
\hline \% other lipids & 14.0 & 14.0 & 14.0 & 14.0 & 0.00 & 0.00 \\
\hline
\end{tabular}

$\mathrm{B} 11=$ raw maize; $\mathrm{B} 22=$ germinated maize; $\mathrm{B} 33=$ steeped maize; $0.72=$ conversion of crude fat to fatty acid

Table 4. Energy density in raw maize (B11), germinated maize (B22) and steeped maize (B33) from carbohydrate, crude Fat and crude protein

\begin{tabular}{|l|l|l|l|l|l|l|}
\hline Parameter & B11 $(\%)$ & B22 $(\%)$ & B33 (\%) & Mean & SD & CV\% \\
\hline $\begin{array}{l}\text { Energy } \\
\text { (kcal/100g)in: }\end{array}$ & & & & & & \\
\hline Protein & $43.7(11.1)$ & $52.2(13.0)$ & $52.7(13.2)$ & 49.5 & 5.06 & 10.2 \\
\hline Carbohydrate & $303(77.3)$ & $297(74.4)$ & $302(75.5)$ & 301 & 3.21 & 1.07 \\
\hline Crude fat & $45.5(11.6)$ & $50.3(12.6)$ & $45.5(11.4)$ & 47.1 & 2.77 & 5.88 \\
\hline Total & 392 & 400 & 400 & 397 & 4.62 & 1.16 \\
\hline $\begin{array}{l}\text { Energy } \\
\text { (kJ/100g)in: }\end{array}$ & $186(11.2)$ & $222(13.1)$ & $135(8.40)$ & 181 & 43.7 & 24.2 \\
\hline Protein & $1289(77.6)$ & $1264(74.7)$ & $1285(80.0)$ & 1279 & 13.4 & 1.05 \\
\hline Carbohydrate & $187(11.3)$ & $207(12.2)$ & $187(11.6)$ & 194 & 11.5 & 5.96 \\
\hline Crude fat & 1662 & 1693 & 1607 & 1654 & 43.6 & 2.63 \\
\hline Total & 6.66 & 7.80 & 7.92 & 7.46 & 0.695 & 9.32 \\
\hline $\begin{array}{l}\text { UEDP }(\%) \text { in: } \\
\text { Kcal }\end{array}$ & 6.72 & 7.86 & 5.04 & 6.54 & 1.42 & 21.7 \\
\hline kJ & & & & & \\
\hline
\end{tabular}

UEDP $=$ utilization of $60 \%$ of proportion of total energy due to protein percent

The total energy density for each sample was shown in Table 4. Both crude fat and protein contributed low values into the energy density whereas carbohydrate contributed very high percentage. The total energy density $(\mathrm{kcal} / 100 \mathrm{~g})$ in the samples ran thus: B11 (392) with percentage contribution of $11.1 \%$ (protein), $11.6 \%$ (crude fat) and $77.3 \%$ (carbohydrate); in B22, total energy was 400 having distribution of $13.0 \%$ (protein), $12.6 \%$ (fat) and 74.4\% (carbohydrate); and in B33 we have total energy of $400 \mathrm{kcal} / 100 \mathrm{~g}$ with protein being
$13.2 \%$, fat (11.4\%) and carbohydrate (75.5\%). For energy in $\mathrm{kJ} / 100 \mathrm{~g}$, total energy was B11 (1662), B22 (1693) and B33 (1607) with percentage distribution virtually similar to the observation in $\mathrm{kcal} / 100 \mathrm{~g}$. On the whole $\mathrm{CV} \%$ showed that the energy values were close. $\mathrm{CV} \%$ range was 1.05 24.2. The total energy values of $1.61-1.69 \mathrm{~mJ} / 100 \mathrm{~g}$ were close to the literature energy ranges of cereals put at 1.61-1.71 MJ/100g (Paul and Southgate, 1978). About 50-60\% of somebody's total daily calories should come from carbohydrate. 
Carbohydrate contains mostly glucose and gives the quickest form of energy. The body has the capacity to change $100 \%$ carbohydrate to glucose.

This is even lower than the recommended safe level of $8 \%$ for adult man that requires 55 protein per day with 60\% utilization (Femi et al., 2015). This is not high enough to prevent energy malnutrition in children and adults that depend solely on maize as the main protein source. It is important to note that ogi produced from cereals is inherently deficient in nutrients, especially protein and cannot guarantee an adequate supply of nutrients (Femi et al., 2015). Such deficies may result in protein malnutrition among ogi consumers particularly the young children who are fed with the product as weaning food. Ogi has been reported as contributing to the prevalence of kwashiorkor among infants owing to its high energy density (due to carbohydrate) and reduced proteins (Sengev and Nwobi, 2016). The recommended PEF\% from food sources is $30 \%$ of the total energy requirement (NACNE, 1983) or the value of 35\% (COMA, 1984) for total energy intake. The present $\mathrm{PEF} \%$ value of 11.4-12.6 were much lower than the two extreme energy levels. This might be an advantage
The utilizable energy due to protein (UEDP\%) was low at $5.04-7.88(\mathrm{~kJ}$ model) and $6.66-7.92(\mathrm{kcal}$ model), assumption of $60 \%$ of protein utilization. and useful to people wishing to adopt the guidelines for a healthy diet.

For energy need, the daily energy requirement for infants is $740 \mathrm{kcal}$ (Bingham, 1978). From Table 5, this translated that an infant would have to consume about 189g (raw), 185g (germinated) and $185 \mathrm{~g}$ (steeped) to satisfy its needs per day. Sample total in $\mathrm{kcal} / 100 \mathrm{~g}$ was also indicated in the Table 5. As changes occur in dietary, nutritional status and age of an animal, appreciable shifts occur in the tissue compartments water and protein levels (Cowgwill, 1958). For effective utilization and conversation of food within the human body, water is indispensable (Snively Jr., and Wessener, 1954), this is because the water content of the body changes with the types of diet (White House Conferences, 1932). This important connection of water with other food substances is the fact that the biochemical basis for this relationship arises from the fact that the water deficit created by protein metabolism is about seven times that for equivalent calories of carbohydrates or fat.

Table 5. Calculated energy requirements for infants and water required for complete metabolism by the

\begin{tabular}{|l|l|l|l|l|l|}
\hline Sarameters & B11 & B22 & B33 & Mean \pm SD & CV\% \\
\hline Daily infant energy requirement (kcal) & 740 & 740 & 740 & $740 \pm 0.00$ & 0.00 \\
\hline Sample total kcal/100g & 392 & 400 & 400 & $397 \pm 4.62$ & 1.16 \\
\hline Sample equivalent/gramme & 189 & 185 & 185 & $186 \pm 2.31$ & 1.24 \\
\hline Protein energy (kcal/100g; X) & 43.7 & 52.2 & 52.2 & $49.5 \pm 5.06$ & 10.2 \\
\hline $\begin{array}{l}\text { Kcal equivalent for water excretion; X× } \\
3^{a}(=\text { y) }\end{array}$ & 131 & 157 & 158 & $149 \pm 15.3$ & 10.3 \\
\hline $\begin{array}{l}\text { Water deficit } \\
\text { 3.5b } \times \text { X }(=\text { Z) }\end{array}$ & 153 & 183 & 184 & $173 \pm 17.6$ & 10.2 \\
\hline $\begin{array}{l}\text { Water required for complete metabolism } \\
=\text { Z-Y }\left(\mathrm{cm}^{3}\right)\end{array}$ & 21.9 & 26.1 & 26.4 & $24.8 \pm 2.52$ & 10.1 \\
\hline
\end{tabular}

$\mathrm{B} 11$ = raw maize seed; B22 = germinated maize; B33 $=$ steeped maize; $^{\mathrm{a}}=1$ calorie of protein requires $3.0 \mathrm{ml}$ water for excretion of the urea and sulphate formed from it; ${ }^{b}=$ water deficit $=350 / 100$ (3.5); $\mathrm{SD}=$ standard deviation; $\mathrm{CV}=$ coefficient of variation percent

Therefore, in young children an increase in calories from carbohydrate causes hydration; whereas an increase in calories from proteins causes dehydration (Pratt and Snyderman, 1953). The increased output of ketones and acids that accompanies a shift to high-fat diets is associated 
with increased water loss that can be offset by increase in carbohydrate intake. Protein quality as well influences the degree of tissue hydration. Albanese (1959) had estimated grammes of water needed for complete metabolism of 100 calories of some food substances. Food materials (protein, starch and fat) all have pre-formed water of $0.00 \mathrm{ml}$ in each case; water gained by oxidation: 10.3 (protein), 13.9 (starch) and 11.9 (fat); lost in dissipating heat: 60.0 for each of the food materials; water lost in excreting end products ( 1 calorie of protein requires $3.0 \mathrm{ml}$ of water for the excretion of the urea and sulphate formed from it, $1 \mathrm{~g}$ of ash requires $65 \mathrm{ml}$ of water for its excretion): 300 (protein), both 0.00 in starch and fat; deficit : 350 (protein), 46 (starch) and 48 (fat). Shown in Table 6 , the following protein energy values were shown: B11 (43.7 kcal), B22 (52.2 kcal) and B33 (52.7 kcal) g/100g sample. Column 3 in Table 6 showed the kcal equivalent of water needed for urea and sulphate excretion and column 4 showed the water deficit. To balance for the water deficit, column 5 showed the values to range from $21.9-26.4 \mathrm{ml}$. Distribution of values ran thus (ml): B11 (21.9) $<$ B22 (26.1) < B33 (26.4). These water deficit values were low because the protein content of each sample was low.

In Table 6 we have the statistical evaluation of the data from Table 1. The comparisons were $\mathrm{B} 11 / \mathrm{B} 22$, B11/B33 and B22/B33. In all the comparisons, $\mathrm{r}_{\mathrm{xy}}$ was values positively high and significant with values ranging between $0.9996-$ 0.9999 with the trend being B11/B22 > B11/B33 $>$ B22/B33. These high $\mathrm{r}_{\mathrm{xy}}$ levels were followed by similar $\mathrm{r}_{\mathrm{xy}}^{2}$ (variance) levels of $0.9992-0.9999$. In the $\mathrm{R}_{\mathrm{xy}}$, we B11/B22 (0.9922) < B11 / B33 (1.01) 三 B22 / B33 (1.01).

Table 6. Statistical analysis of the data from Table 1 concerning the proximate composition of raw (B11), germinated (B22) and steeped grains of Zea mays

\begin{tabular}{|l|l|l|l|l|l|l|l|l|l|}
\hline \multirow{2}{*}{ Statistics } & \multicolumn{3}{|l}{ Raw/Germinated } & \multicolumn{3}{l|}{ Raw / Steeped } & \multicolumn{3}{l|}{ Germinated / Steeped } \\
\cline { 2 - 11 } & $\mathrm{B} 11$ & & $\mathrm{~B} 22$ & $\mathrm{~B} 11$ & & $\mathrm{~B} 33$ & $\mathrm{~B} 22$ & & $\mathrm{~B} 33$ \\
\hline $\mathrm{r}_{\mathrm{xy}}$ & & 0.9996 & & & 0.9997 & & & 0.9999 & \\
\hline $\mathrm{R}_{\mathrm{xy}}{ }^{2}$ & & 0.9992 & & & 0.9994 & & & 0.9999 & \\
\hline Rxy & & 0.9922 & & & 1.01 & & & 1.01 & \\
\hline Mean & 35.9 & & 36.2 & 35.9 & & 35.9 & 36.2 & & 36.2 \\
\hline SD & 43.3 & & 43.4 & 43.3 & & 43.3 & 43.4 & & 43.8 \\
\hline CV\% & 121 & & 120 & 121 & & 121 & 120 & & 121 \\
\hline $\mathrm{C}_{\mathrm{A}}$ & & 0.0284 & & & 0.0241 & & & 0.0100 & \\
\hline IFE & & 0.9716 & & & 0.9759 & & & 0.9900 & \\
\hline Remark & & $*$ & & & $*$ & & & $*$ & \\
\hline
\end{tabular}

$\mathrm{r}_{\mathrm{xy}}=$ correlation coefficient; $\mathrm{r}_{\mathrm{xy}}{ }^{2}=$ variance; $\mathrm{R}_{\mathrm{xy}}=$ regression coefficient; $\mathrm{C}_{\mathrm{A}}=$ coefficient of alienation; IFE $=$ index of forecasting efficiency; ${ }^{*}=$ Results were significantly different a t $n-2$ and $r_{=0.01}$ (critical value $=0.834$ ) $[\mathrm{NOTE}$ : $\mathrm{n}-2=$ $8-2=6 \mathrm{df})$

The mean values were close at $35.9 \pm 43.3-$ $36.2 \pm 43.4 \mathrm{~g} / 100 \mathrm{~g}$ whereas the $\mathrm{CV} \%$ values were also very close at $120-121$. The $\mathrm{C}_{\mathrm{A}}$ (coefficient of alienation) was generally low at 0.0100-0.0284 with corresponding high but inverse relationship of $0.9716-0.9900$. The values of $0.9716-0.9900$ were index of forecasting efficiency (IFE) values. IFE is a reverse of $\mathrm{C}_{\mathrm{A}}$; also, IFE $+\mathrm{C}_{\mathrm{A}}=1.0$ or $100 \%$. Whereas $\mathrm{C}_{\mathrm{A}}$ designates error value in forecasting the relationship between two compared entities, IFE represents the reduction in the error of predicting the relationship between two compared entities. When $\mathrm{C}_{\mathrm{A}}<\mathrm{IFE}$, prediction of relationship is easy but vice versa when the $\mathrm{C}_{\mathrm{A}}>\mathrm{IFE}$. From Table -7 , reduction in error of prediction of relationship ranged between 97.3 - 99.0. Since IFE $>\mathrm{C}_{\mathrm{A}}$ in each case, each member of a pair would be able to carry out the metabolic functions of the other pair member and vice versa. 
In Table 7, we have the display of the mineral profiles of the samples. The least concentrated mineral was $\mathrm{Pb}$ which had similar value of $<0.001$ $\mathrm{mg} / 100 \mathrm{~g}$ in each of the samples. Minerals of high concentration were K $(550-661 \mathrm{mg} / 100 \mathrm{~g})$. P (369$401 \mathrm{mg} / 100 \mathrm{~g})$ and $\mathrm{Mg}(220-235 \mathrm{mg} / 100 \mathrm{~g})$ with B22 predominating in each of the samples. Moderate mineral values were observed in $\mathrm{Na}$ (62.2 $81.9 \mathrm{mg} / 100 \mathrm{~g})$ and $\mathrm{Ca}(13.3-20.9 \mathrm{mg} / 100 \mathrm{~g})$; low levels were in Fe $(4.275 .59 \mathrm{mg} / 100 \mathrm{~g}$ and $\mathrm{Zn}(4.24$ $-6.60 \mathrm{mg} / 100 \mathrm{~g})$. Very low mineral levels were in
$\mathrm{Cu}, \mathrm{Co}, \mathrm{Mn}$ and Se. Enhanced minerals in B22 greater than $\mathrm{B} 11$ and $\mathrm{B} 33$ were $\mathrm{Fe}, \mathrm{Cu}, \mathrm{Co}, \mathrm{Mn}, \mathrm{Zn}$, $\mathrm{Mg}, \mathrm{K}, \mathrm{P}$ and Se whereas similar minerals in B33 were $\mathrm{Ca}$ and $\mathrm{Na}$. The $\mathrm{CV} \%$ values were generally low with highest $\mathrm{CV} \%$ being 25.8 in $\mathrm{Mn}$ and $\mathrm{CV} \%$ of 0.00 in $\mathrm{Pb}$ (being the lowest $\mathrm{CV} \%$ ). The total sample loads of the samples were $(\mathrm{mg} / 100 \mathrm{~g})$ : B11 $(1227)<$ B22 $(1403)>$ B33 (1313). The percentage values of each mineral in each sample were indicated in the Table 8.

Table 7. Mineral profiles (mg/100g) of raw (B11) germinated (B22) and steeped (B33) grains of Zea mays

\begin{tabular}{|c|c|c|c|c|c|c|}
\hline Mineral & B11 (\%) & B22 (\%) & B33 (\%) & Mean & SD & $\mathrm{CV} \%$ \\
\hline $\mathrm{Fe}$ & $4.42(0.361)$ & $5.59(0.398)$ & $4.27(0.325)$ & 4.76 & 0.723 & 15.2 \\
\hline $\mathrm{Cu}$ & $0.543(0.044)$ & $0.811(0.0580$ & $0.513(0.040)$ & 0.628 & 0.158 & 25.2 \\
\hline $\mathrm{Co}$ & $0.008(0.001)$ & $0.012(0.001)$ & $0.009(0.001)$ & 0.010 & 0.002 & 21.5 \\
\hline $\mathrm{Mn}$ & $0.864(0.070)$ & $1.28(0.092)$ & $0.817(0.062)$ & 0.987 & 0.255 & 25.8 \\
\hline $\mathrm{Zn}$ & $4.24(0.345)$ & $6.60(0.471)$ & $5.68(0.432)$ & 5.51 & 1.19 & 21.6 \\
\hline $\mathrm{Pb}$ & $<0.001(0.0001)$ & $<0.001(0.0001)$ & $<0.001(0.0001)$ & 0.001 & 0.00 & 0.00 \\
\hline $\mathrm{Ca}$ & $13.3(1.09)$ & $16.5(1.17)$ & $20.9(1.59)$ & 16.9 & 3.82 & 22.6 \\
\hline $\mathrm{Mg}$ & $220(17.9)$ & $235(16.8)$ & $230(17.5)$ & 228 & 7.64 & 3.34 \\
\hline $\mathrm{K}$ & $550(44.8)$ & $661(47.1)$ & $600(45.7)$ & 604 & 55.6 & 9.21 \\
\hline $\mathrm{Na}$ & $62.2(5.07)$ & $74.8(5.34)$ & $81.9(6.23)$ & 73.0 & 9.98 & 13.7 \\
\hline $\mathrm{P}$ & $371(30.2)$ & $401(28.6)$ & $369(28.1)$ & 380 & 17.9 & 4.71 \\
\hline $\mathrm{Se}$ & $0.028(0.002)$ & $0.036(0.003)$ & $0.032(0.002)$ & 0.032 & 0.004 & 12.5 \\
\hline Total & 1227 & 1403 & 1313 & 1314 & 88.0 & 6.70 \\
\hline Ratio & \multicolumn{6}{|c|}{$\mathrm{B} 11 / \mathrm{B} 22=0.875: 1.00 ; \mathrm{B} 11 / \mathrm{B} 33=0.935: 1.00 ; \mathrm{B} 22 / \mathrm{B} 33=1.07: 1.00$} \\
\hline \multicolumn{7}{|c|}{ Superiority of B22 over B11 and B33 } \\
\hline \multicolumn{7}{|c|}{$\mathrm{B} 22>\mathrm{B} 11 ; 12 / 12=100 \% ; \mathrm{B} 22>\mathrm{B} 33 ; 10 / 12=83.3 \% ; \mathrm{B} 33>\mathrm{B} 11 ; 8 / 12=66.7 \%$. i.e. $\mathrm{B} 22>\mathrm{B} 33>\mathrm{B} 11$} \\
\hline
\end{tabular}

Minerals of significant percentage levels were: $\mathrm{Mg}$ $(16.8$ - 17.9\%), K (44.8-47.1\%) and P (28.1$30.2 \%)$. Values of percentage levels greater than 1.0 were observed in $\mathrm{Na}$ (5.07-6.23\%) and $\mathrm{Ca}(1.09$ $-1.59 \%$ ) whilst all others were less than $1.00 \%$ each. The superiority (in concentration) of B22 over $\mathrm{B} 11$ and $\mathrm{B} 33$ ran thus: $\mathrm{B} 22>\mathrm{B} 11,12 / 12=$
$100 \%$; B22 $>\mathrm{B} 33,10 / 12=83.3 \%$; B33 $>\mathrm{B} 11,8 / 12=$ $66.7 \%$; that is $\mathrm{B} 22>\mathrm{B} 33>\mathrm{B} 11$.

The improvement status of the minerals was qualitatively displayed in Table 8 . These minerals were under "definite improvement $(++)$ " in B22: $\mathrm{Fe}, \mathrm{Cu}, \mathrm{Co}, \mathrm{Mn}$ and $\mathrm{K}$ whereas it was only $\mathrm{Na}$ in B33 since they were considerably improved in their corresponding samples. Minerals classified under 
"usually some improvement $(+)$ " cut across the samples (B11, B22, B33) and no improvement (-) was observed only in $\mathrm{Pb}$ for the samples.

Table 8. Improvement status of the minerals of maize grains during sprouting and fermentation

\begin{tabular}{|l|l|l|l|}
\hline Mineral & Raw grains & Germinated grains & Steeped grains \\
\hline $\mathrm{Fe}$ & + & ++ & + \\
\hline $\mathrm{Cu}$ & + & ++ & + \\
\hline $\mathrm{Co}$ & + & ++ & + \\
\hline $\mathrm{Mn}$ & + & ++ & + \\
\hline $\mathrm{Zn}$ & + & + & + \\
\hline $\mathrm{Pb}$ & - & - & - \\
\hline $\mathrm{Ca}$ & + & + & ++ \\
\hline $\mathrm{Mg}$ & + & + & + \\
\hline $\mathrm{K}$ & + & ++ & + \\
\hline $\mathrm{Na}$ & + & + & ++ \\
\hline $\mathrm{P}$ & + & + & + \\
\hline $\mathrm{Se}$ & + & + & + \\
\hline Total & + & + & + \\
\hline
\end{tabular}

$++=$ definite improvement; $+=$ usually some improvement; $-=$ no improvement

Minerals are necessary for life. Mn has always been low in the Nigerian food sources. Examples: in eight organs of African giant pouch rat (Cricetomys gambianus) (Adeyeye and Adesina, 2018), Mn was not detected in them but recorded $1.86 \mathrm{mg} / 100 \mathrm{~g}$ (muscle) and $0.01 \mathrm{mg} / 100 \mathrm{~g}$ (skin) in the same animal; it was $1.9 \pm 0.04 \mathrm{mg} / \mathrm{kg}$ (meat pie), $1.0 \pm 0.00 \mathrm{mg} / \mathrm{kg}$ (doughnut), $2.9 \pm 0.01 \mathrm{mg} / \mathrm{kg}$ (moin moin) and $2.80 \pm 0.01 \mathrm{mg} / \mathrm{kg}$ (cake) (Adeyeye et al., 2012). Both $\mathrm{Co}$ and $\mathrm{Cu}$ are minor but essential minerals which were also low in the samples under discussion. Fe was at moderate level in the samples ranging from $4.27-5.59 \mathrm{mg} / 100 \mathrm{~g}$; these values were low to the needed $\mathrm{Fe}$ in human metabolism. Usually about $1-10 \%$ of Fe from plant sources is usually absorbed by the body although this value can be improved upon when plants are consumed with meat or other animal Fe source (Adeyeye et al., 2012). Minimum Zn allowance (about $15-20 \mathrm{mg} /$ day) could not be met by any of the samples. Zinc is a major constituent of the body tissues and it is a component of more than 50 enzymes (Adeyeye et al., 2012). Calcium is an important constituent of body fluids being a coordinator of inorganic elements particularly $\mathrm{K}$, $\mathrm{Mg}$ or $\mathrm{Na}$ where $\mathrm{Ca}$ is capable of assuming a corrective role when such metals are in excessive amount in the body (Fleck, 1976). Ca, P and vitamin D combine together to avoid rickets in children and osteoporosis (bone thinning) among older people (Adeyeye et al., 2012). A dietary regime of adequate dietary Ca over the years would be a deterrent to this condition. Phosphorus has always been found with $\mathrm{Ca}$ in the body, both contributing to the supportive structures of the body. Phosphorus exists in cells and in blood as soluble phosphate ion, as well as in lipids, proteins, carbohydrate and energy transfer enzymes (Adeyeye et al., 2012). Mg was the third highest concentrated mineral in the samples; it is an activator of many enzyme systems and also maintains the electrical potential in nerves. Potassium is primarily an intercellular cation in large part being bound to protein and together with $\mathrm{Na}$ influences osmotic pressure and contributes to normal $\mathrm{pH}$ equilibrium (Adeyeye et al., 2012).

In Table 9, differences in the mineral profiles of maize samples between B11/B22, B11/B33 and B22/B33 were shown, and accompanied by the percentage differences. Percentage differences of 50 and $>50$ were observed in Co $(-50.0$, B11 -B22) 
and $\mathrm{Zn}(-55.9, \mathrm{~B} 11$ - B22), all being positive towards $\mathrm{B} 22$; in $\mathrm{B} 11-\mathrm{B} 33, \mathrm{Ca}$ and value of $-56.7 \%$ (being positive towards $\mathrm{B} 33$ ) and none in that range for B22-B33. The low level of differences showed the low differences between the compared samples.

Table 9. Differences in the mineral profiles of Zea mays between raw/germinated (B11-B22), raw/fermented (B11-B33) and germinated / fermented (B22-B33) grains

\begin{tabular}{|l|l|l|l|}
\hline Mineral & B11 - B22 (\%) & B11-B33 $(\%)$ & B22- B33 (\%) \\
\hline $\mathrm{Fe}$ & $-1.16(-26.2)$ & $+0.150(+3.39)$ & $+1.31(+23.5)$ \\
\hline $\mathrm{Cu}$ & $-0.268(-49.4)$ & $+0.012(+2.21)$ & $+0.280(+34.5)$ \\
\hline $\mathrm{Co}$ & $-0.004(-50.0)$ & $-0.001(-12.5)$ & $+0.003(+25.0)$ \\
\hline $\mathrm{Mn}$ & $-0.419(-48.5)$ & $+0.047(+5.42)$ & $+0.466(+36.3)$ \\
\hline $\mathrm{Zn}$ & $-2.37(-55.9)$ & $-1.44(-34.1)$ & $+0.924(+14.0)$ \\
\hline $\mathrm{Pb}$ & $0.00(0.00)$ & $0.00(0.00)$ & $0.00(0.00)$ \\
\hline $\mathrm{Ca}$ & $-3.13(-23.5)$ & $-7.55(-56.7)$ & $-4.42(-26.8)$ \\
\hline $\mathrm{Mg}$ & $-15.2(-6.89)$ & $-10.0(-4.59)$ & $+5.07(+2.15)$ \\
\hline $\mathrm{K}$ & $-110(-20.0)$ & $-50.0(-9.09)$ & $+60.2(+9.11)$ \\
\hline $\mathrm{Na}$ & $-12.7(-20.4)$ & $-19.7(-31.7)$ & $-7.05(-9.42)$ \\
\hline $\mathrm{P}$ & $-30.5(-8.33)$ & $+1.92(+0.519)$ & $+32.4(+8.08)$ \\
\hline $\mathrm{Se}$ & $-0.008(-28.6)$ & $-0.004(-14.3)$ & $+0.004(+11.1)$ \\
\hline Total & $-176(-14.3)$ & $-86.7(-7.07)$ & $+89.2(+6.36)$ \\
\hline
\end{tabular}

$+=$ in the two compared values, when sample in the left is higher than the right hand, the sign is positive and vice versa

A study by Zhang et al. (Zhang et al., 2015) on buckwheat showed that phytic acid in buckwheat decreased with increase in the germination time due to activation of phytase which hydrolyses phytic acid into phosphoric acid and myinositol thereby making minerals more bioavailable (Liang et al., 2008; Mbithi et al., 2000). Mineral availability had been said to be grain specific with highest availability for $\mathrm{Fe}$ in wheat, $\mathrm{Zn}$ in rice and wheat, $\mathrm{Mn}$ in rice and soybean and $\mathrm{Ca}$ in soybean, rice and faba beans (Luo et al., 2015). The difference in mineral availability from different cereals and also legumes after germination for similar period may be related to differences in phytate content, phytase activation, extent of binding of minerals within the matrix, or interaction of these factors. Malting of sorghum, foxtail and chickpea significantly increased the content of $\mathrm{Na}, \mathrm{K}, \mathrm{P}, \mathrm{Ca}$ and $\mathrm{Mg}$ (Desal et al., 2010; Idris et al., 2007; Laxmi et al., 2015) but decreased $\mathrm{Ca}$ and Fe (Desal et al., 2010; Laxmi et al., 2015; Ogbonna et al., 2012). This difference could be accounted for by different processing methods such as steeping times and freeing of bound minerals during malting (Onyango et al., 2013).

Table 10 contained the various computed mineral ratios which were: $\mathrm{Ca} / \mathrm{Mg}, \mathrm{Ca} / \mathrm{K}, \mathrm{Zn} / \mathrm{Cu}$, $\mathrm{Ca} / \mathrm{P}, \mathrm{Fe} / \mathrm{Cu}, \mathrm{Ca} / \mathrm{Pb}, \mathrm{Fe} / \mathrm{Pb}, \mathrm{Fe} / \mathrm{Co}, \mathrm{Na} / \mathrm{Mg}, \mathrm{K} / \mathrm{Co}$, $\mathrm{Na} / \mathrm{K}, \mathrm{Zn} / \mathrm{Pb}$ and $\mathrm{K}[(\mathrm{Ca}+\mathrm{Mg})]$. Mineral ratios normally reveal the important balance between the elements, provision of information regarding the many factors they may be represented by a disruption of their relationships, such as disease states, physiological and developmental factors, the effects of diet and drugs (Watts, 2010). 
Table 10. Mineral ratios of the minerals analyzed for in the variously treated maize samples

\begin{tabular}{|c|c|c|c|c|c|c|}
\hline $\begin{array}{l}\text { Appropriate } \\
\text { minerals }\end{array}$ & $\begin{array}{l}\text { Mineral } \\
\text { ratio }\end{array}$ & $\begin{array}{l}\text { (Reference } \\
\text { balance ideal) }\end{array}$ & $\begin{array}{l}\text { Acceptable } \\
\text { ideal range }\end{array}$ & B11 & B22 & B33 \\
\hline $\mathrm{Fe}$ & $\mathrm{Ca} / \mathrm{Mg}$ & 7.00 & 3 to 11 & 0.061 & 0.070 & 0.091 \\
\hline $\mathrm{Cu}$ & $\mathrm{Ca} / \mathrm{K}$ & 4.20 & 2.2 to 6.2 & 0.024 & 0.025 & 0.035 \\
\hline $\mathrm{Co}$ & $\mathrm{Zn} / \mathrm{Cu}$ & 8.00 & 4 to 12 & 7.80 & 8.14 & 10.7 \\
\hline $\mathrm{Mn}$ & $\mathrm{Ca} / \mathrm{P}$ & 2.60 & 1.5 to 3.6 & 0.036 & 0.041 & 0.057 \\
\hline $\mathrm{Zn}$ & $\mathrm{Fe} / \mathrm{Cu}$ & 0.90 & 0.2 to 1.6 & 8.15 & 6.89 & 8.05 \\
\hline $\mathrm{Pb}$ & $\mathrm{Ca} / \mathrm{Pb}$ & 84.0 & 126 to 168 & 13318 & 16451 & 20866 \\
\hline $\mathrm{Ca}$ & $\mathrm{Fe} / \mathrm{Pb}$ & 4.40 & 6.6 to 8.8 & 4424 & 5585 & 4274 \\
\hline $\mathrm{Mg}$ & $\mathrm{Fe} / \mathrm{Co}$ & 440 & $\mathrm{-a}^{\mathrm{a}}$ & 553 & 465 & 475 \\
\hline $\mathrm{K}$ & $\mathrm{Na} / \mathrm{Mg}$ & 4.00 & 2 to 6 & 0.282 & 0.318 & 0.356 \\
\hline $\mathrm{Na}$ & $\mathrm{K} / \mathrm{Co}$ & 2000 & $-\mathrm{a}^{\mathrm{a}}$ & 68807 & 55054 & 66718 \\
\hline \multirow[t]{3}{*}{$\mathrm{P}$} & $\begin{array}{l}\mathrm{K} /[(\mathrm{Ca}+ \\
\mathrm{Mg})]\end{array}$ & 2.2 & $-a$ & 4.72 & 5.25 & 4.78 \\
\hline & $\mathrm{Na} / \mathrm{K}$ & 2.40 & 1.4 to 3.4 & 0.113 & 0.113 & 0.136 \\
\hline & $\mathrm{Zn} / \mathrm{Pb}$ & $-{ }^{a}$ & $-\mathrm{a}^{\mathrm{a}}$ & 4235 & 6603 & 5679 \\
\hline
\end{tabular}

Of all the ratio values, only $\mathrm{Zn} / \mathrm{Cu}(7.80-10.7)$ fell within the acceptable ideal range of 4-12 whereas all other ratios fell much below the acceptable ideal range. The advantages / disadvantages of such lower than ideal acceptable range had been variously discussed (Watts, 2010; Adeyeye et al., 2017; Nieman et al., 1992; Adeyeye et al., 2012; National Research Council, 1989).

Table 11. Statistical analysis of the data from Table 8 concerning the mineral profiles of raw (B11), germinated (B22) and fermented grains of Zea mays

\begin{tabular}{|l|l|l|l|l|l|l|l|l|l|}
\hline \multirow{2}{*}{ Statistics } & \multicolumn{3}{|l}{ Raw Versus Germinated } & \multicolumn{3}{l}{ Raw Versus Fermented } & \multicolumn{3}{l|}{ Germinated Versus Fermented } \\
\cline { 2 - 10 } & $\mathrm{B} 11$ & & $\mathrm{~B} 22$ & $\mathrm{~B} 11$ & & $\mathrm{~B} 33$ & $\mathrm{~B} 22$ & & $\mathrm{~B} 33$ \\
\hline $\mathrm{r}_{\mathrm{xy}}$ & & 0.9983 & & & 0.9986 & & & 0.9995 & \\
\hline $\mathrm{r}_{\mathrm{xy}}{ }^{2}$ & & 0.9966 & & & 0.9972 & & & 0.9991 & \\
\hline $\mathrm{R}_{\mathrm{xy}}$ & & 1.16 & & & 1.06 & & & 0.9132 & \\
\hline Mean & 102 & & 117 & 102 & & 109 & 117 & & 109 \\
\hline $\mathrm{SD}$ & 183 & & 212 & 183 & & 194 & 212 & & 194 \\
\hline $\mathrm{CV} \%$ & 179 & & 181 & 179 & & 177 & 181 & & 177 \\
\hline $\mathrm{C}_{\mathrm{A}}$ & & 0.0586 & & & 0.0532 & & & 0.0303 & \\
\hline IFE & & 0.9414 & & & 0.9468 & & & 0.9697 & \\
\hline Remark & & Significant & & & Significant & & & Significant & \\
\hline
\end{tabular}

$\mathrm{r}_{\mathrm{xy}}=$ correlation coefficient; $\mathrm{r}_{\mathrm{xy}}{ }^{2}=$ variance; $\mathrm{R}_{\mathrm{xy}}=$ regression coefficient; $\mathrm{SD}=$ standard deviation; $\mathrm{CV} \%=$ coefficient of variation percent; $\mathrm{C}_{\mathrm{A}}=$ coefficient of alienation; IFE $=$ index of forecasting efficiency; $\mathrm{r}_{\mathrm{xy}}=$ significant at $n-2$ and $r_{0.01}($ critical value $=0.708)$ [NOTE: $n-2=12-2=10 \mathrm{df}$ ] 
The statistical analysis results of the data from Table 7 had been profiled in Table 11. All the $r_{x y}$ values were positively high and significant at $r_{=0.01}$; this was followed by high values of $r_{x y}{ }^{2} . R_{x y}$ were high at $0.9132-1.16$. Both mean, SD and CV\% were higher than observed in the proximate statistical results. The $\mathrm{C}_{\mathrm{A}}$ values were higher than reported for the proximate values but still lower than their corresponding IFE levels in the minerals; this made comparison between B11/B22, B11/B33 and B22/B33 easy since all $\mathrm{C}_{\mathrm{A}}<$ all IFE.
Figure 1 had all the mineral safety index (MSI) values of $\mathrm{Fe}, \mathrm{Ca}, \mathrm{P}, \mathrm{Mg}, \mathrm{Zn}, \mathrm{Cu}$, Se and $\mathrm{Na}$ in the maize samples. Levels of MSI within the 10th unit range were in $\mathrm{Mg}(8.26-8.82), \mathrm{Cu}(5.84-8.92)$, $\mathrm{Se}$ (5.60 - 7-20), P (3.07 - 3.34) and Fe (1.91 - 2.49), whereas only $\mathrm{Zn}$ was in the 20th unit range (9.32 14.5); other MSI for $\mathrm{Ca}$ and $\mathrm{Na}$ had values less than 1.00. Highest MSI values were observed in B22 for Fe, $\mathrm{P}, \mathrm{Mg}, \mathrm{Zn}, \mathrm{Cu}$ and $\mathrm{Se}$.

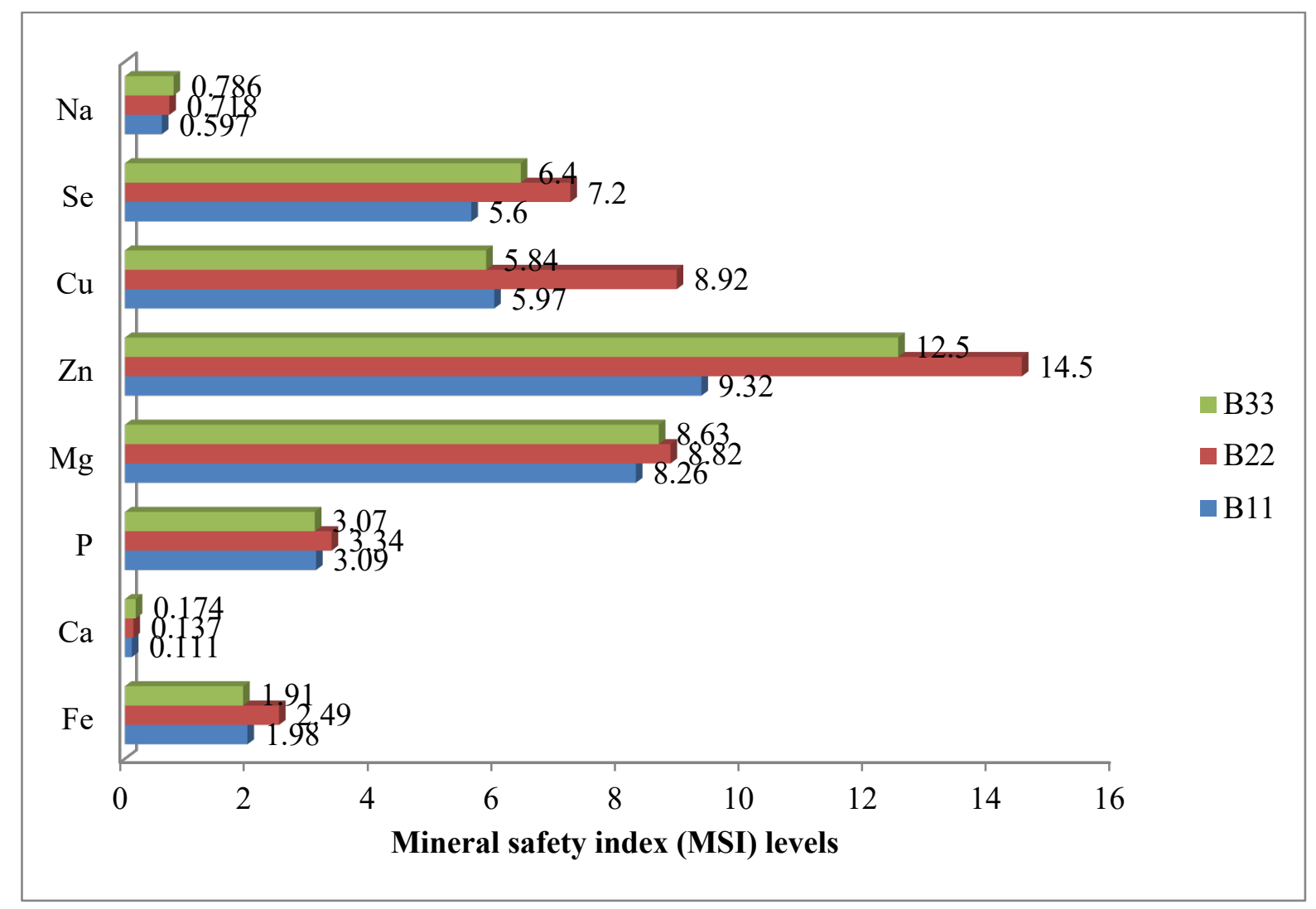

Figure 1. Mineral safety index (MSI) of Fe, $\mathrm{Ca}, \mathrm{P}, \mathrm{Mg}, \mathrm{Zn}, \mathrm{Cu}$, Se and $\mathrm{Na}$ of Zea mays grains

In Figure 2, the MSI differences between the standard MSI values and the sample calculated MSI values from Zea mays samples were profiled. All the calculated MSI values were less than the standard MSI values. The implication of this would be that none of the minerals would have any deleterious effect on any of the sample consumers. The percentage differences showed that the following trends could be observed: $\mathrm{Ca}(98.3-$ $98.9 \%), \mathrm{Na}(83.6-87.6 \%), \mathrm{Cu}(73.0-82.3 \%), \mathrm{Fe}$ $(62.8-71.5 \%), \mathrm{Zn}(56.1-71.8 \%)$ whereas others were less than $70.0 \%$. 


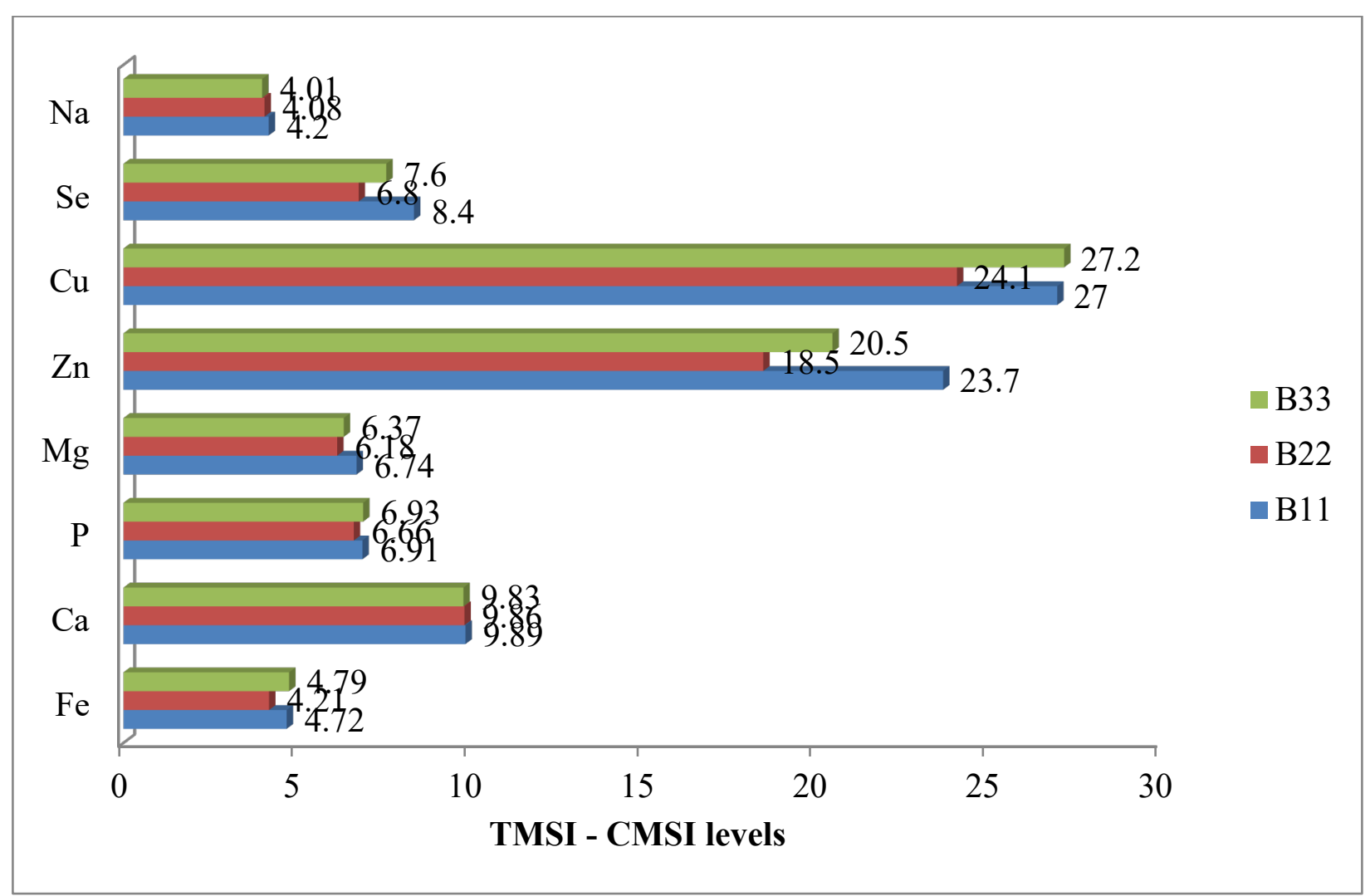

Figure 2. Mineral safety index (MSI) differences between the Table MSI (TMSI) values and sample calculated MSI (CMSI) values from Zea mays samples

\section{Conclusions}

The three differently processed samples of Zea mays L.Dk 818 grains exhibited high and positive significant differences among their compared groups both in the proximate and mineral results. The variations between parameters (both in proximate and minerals) in each sample were low as seen in the $\mathrm{CV} \%$. There was evidence of likely microbial influence in both the steeped and germinated samples both in proximate and minerals. All sample pairs: raw (B11)/ germinated (B22), raw (B11) / steeped (B33) and germinated (B22) / steeped (B33) had low $\mathrm{C}_{\mathrm{A}}$ but corresponding high IFE showing that biochemical vice versa functions can occur in B11/B22, $\mathrm{B} 11 / \mathrm{B} 33$ and B22/B33 both in proximate and mineral levels. To show the better improvement of germination over raw maize, we have $\mathrm{B} 22>\mathrm{B} 11=$ $57.1 \%$ / 42.9\%; B22 over B33, we had B2 $\equiv \mathrm{B} 33 \equiv$ $50.0 \% / 50.0 \%$; but $\mathrm{B} 11>\mathrm{B} 33=62.5 \% / 37.5 \%$ in terms of concentration ratios in the proximate composition. For mineral composition, we had a reverse observation; $\mathrm{B} 22>\mathrm{B} 11,12 / 12=100 \%$; $\mathrm{B} 22>\mathrm{B} 33,10 / 12=83.3 \%$; $\mathrm{B} 33>\mathrm{B} 11,8 / 12=$ $66.7 \%$; i.e. $\mathrm{B} 22>\mathrm{B} 33>\mathrm{B} 11$.

\section{References}

Adeyeye, E.I., Adesina, A.J., Akinsola, A.F., and Olagboye, S.A. (2017). Comparative assessment of the proximate, mineral, vitamin compositions and mineral safety index of some selected domestic animals' furs. Journal of BioInnovation, 6(3), $462-478$.

Adeyeye, E.I., and Adesina, A.J. (2018). Proximate and mineral compositions, mineral safety index (MSI) of ten organs of African gaint pouch rat. International Journal of Pharmacology Phytochemistry and Ethnomedicine, 9, 1-9.

Adeyeye, E.I., Orisakeye, O.T., and Oyarekua, M.A. (2012). Composition, mineral safety index, calcium, zinc and phytate interrelationships in four fast - foods consumed in Nigeria. Bulletin of Chemical Society of Ethiopia, 26(1), 43 - 54 
Agboola, S.A. (1979). Agricultural Atlas of Nigeria. London: Oxford University Press.

Ahmed, S.M. (2013). Millet grains: nutritional quality, processing and potential health benefits. Comprehensive Reviews in Food Science and Food Safety, 12, 281 - 295

Albanese, A.A. (1959). Protein and amino acid nutrition. New York and London: Academic Press.

Analytical Research Labs, Inc. (ARL) (2012). Basic ratios and their meaning. Arizona 85021. USA: Avenue - Phoenix. http://www.alrtma.com/Articles/RatiosDoc

Anazonwu-Bello, J. (1986). Nigerian Corn Recipes. Enugu, Nigeria: ABIC Publishers.

AOAC. (2006). Official Methods of Analysis. Maryland, USA: Association of Official Analytical Chemists, 18th edition.

Bingham, S. (1978). Nutrition: A consumer's guide to good eating. London: Trans World Publishers.

Chase, C.I. (1976). Elementary statistical procedure. (2nd ed.). Tokyo: McGraw-Hill Kogakusha Ltd.

Committee on Medical Aspect (COMA) of Food Policy. (1984). Diet and cardiovascular disease. London: HMSO.

Cowgwill, G.R. (1958). Evaluating body composition. Burden's Review of Nutrition Research, 19, 1-7.

Desal, A.D., Kulkami, S.S., Sahoo, A.K. Ranveer, R.C., and Dandge, P.B. (2010). Effect of supplementation of malted ragi flour on the nutritional and sensorial quality characteristics of cake. Advance Journal of Food Science and Technology, 2, $67-71$

FAO (1968). Food Composition Table for use in Africa: FAO, Nutrition Division, p. 306.

FAOSTAT (2020). FAO of the United Nations last updated June 15, 2020. http://www.fao.org/faostat/en/\#data/QC

Femi, A., Alabi, M.A., Babaniyi, B.R., Obagunwa, M.P., and Ojo, F.A. (2015). Nutrient loss during traditional ogi production. Journal of Chemical and Pharmaceutical Research, 7(12), 246 - 249

Fleck, H. (1976). Introduction to nutrition. (3rd ed.). New York: MacMillan Publishers.
Greenfield, H. and Southgate, D.A.T (2003). Food composition data: Production, Management and Use. Rome: FAO

Hatcock, J.N (1985). Quantitative evaluation of vitamin safety: Pharmacy News, (pp. $104-113$ ).

Idris, W.H., AbdulRahaman, S.M., Elmaki, HB, Babikar, E.E., and Eltinary, A.H. (2007). Effect of malt pre-treatment on HCI extractability of $\mathrm{Ca}, \mathrm{P}$ and $\mathrm{Fe}$ of sorghum (Sorghum bicolor) cultivars. International Journal Food Science, 42, $194-199$.

Ilori, M.O., Fassehatzion, B., Olajuyigbe, O.A., Babalola, G.O., and Ogundiwin, J.O. (1991). Effect of malting and brewing processes on the microorganisms associated with sorghum grains and malt: MBAA Tech. Q, pp. 28:45-49.

International Grains Council (International Organization) (2013). International Grains Council Market Report 28, November 2013.

Jose, M.C. (1966). Proceedings high Lysine corn conference. Washington DC: Corn Indus. Res. Found., pp. 66-67.

Kulp, K. (2000). Handbook of Cereal Science and Technology. (2nd ed,). Boca Raton Florida: C.R.C. Press Inc.

Laxmi, G., Chaturvedi, N., and Richa, S. (2015). The impact of malting on nutritional composition of foxtail millet, wheat and chickpea. Journal of Nutrition and Food Sciences, 5(5), 1 - 3.

Lefyedi, M.L. (2006). Control of microbial proliferation on sorghum during malting, $\mathrm{Ph}$. dissertation. South Africa: University of Pretoria. Available at http.www.upetd.up.ac.Za/Thesis/available/etd06082007-17321.

Liang, J., Han, B.Z., Nout, M.J., and Hamer, R.J (2008). Effects of soaking, germination and fermentation on phytic acid, total and in vivo soluble zinc in brown rice. Food Chemistry, 110, $821-828$.

Luo, Y.W., Xie, W.H., Jin, X.X., Wang, Q., and He, Y.J. (2014). Effects of germination on Fe, Zn, $\mathrm{Ca}, \mathrm{Mn}$ and $\mathrm{Cu}$ availability from cereals and legumes. CyTA - Journal of Food, 12, $22-26$

Maize (2012). Oxford English Dictionary. (online ed.). Accessed June 7, 2012. 
Mbithi-Mwikya, S., Camp, J.V., Yiru, Y., and Huyghebaert, A. (2000). LWT - Food Science and Technology, 33, 9-14.

Milner, R.T. (1954) program on corn use. Amr. Seed Trade Assoc., Hybrid Corn Division, Industrial Review Report, 8, 20 - 30

Muller, H.G.and Tobin, G. (1980). Nutrition and food processing. London: Croom Helm Ltd.

NACNE (National Advisory Committee on Nutrition Education). (1983). Proposal for nutritional guidelines for healthy education in Britain. London: Health Education Council.

National Research Council (NRC). (1989). Food and Nutrition Board Recommended Dietary Allowance. (10th ed.). Washington DC, USA: National Academy Press.

Nieman, D.C., Butterworth, D.E., and Nieman, C.N. (1992). Nutrition. Dubuque, USA: Wm. C. Brown Publishers.

Obi, I. U. (1991). Maize - Its agronomy, diseases, pests and food values. Enugu, Nigeria: Optimal Computer Solutions Ltd.

Ogbonna, A.C., Abuajah, C.I., Ide, E.O., and Udofia, U.S. (2012). Effect of malting conditions on the nutritional and antinutritional factors of sorghum grist. Food Technology, 36, $64-72$.

Ogundiwin, J.O., Ilori, M.O, Fassehatzion, B., Babalola, G.O., and Olajuyigbe, A.O. (1991). Effect of chemical treatments on the microorganisms associated with malting of sorghum grains and sorghum malt. Journal of Applied Bacteriology, 71, 139-143, https://doi.org/10.1111/j.13652672.1991.tb0296 9. $\mathrm{x}$

Oloyo, R.A. (2001). Fundamentals of research methodology of social and applied sciences. Ilaro, Nigeria: ROA Edu. Press.

Onyango, C.A., Ochanda, S.O., Mwasaru, M.A., Ochieng, J.K., Mathooko, F.M., and Kinyuru, J.N. (2013). Effects of malting and fermentationlon anti-nutrient reduction and protein digestibility of red sorghum, white sorghum and pearl millet. Journal of Food Research, 2, 41 - 49
Paul, A., and Southgate, D.A.T. (1978). New food Tables. Nutrition and Food Science, 87(1), 2 - 3

Pearson, D. (1976). Chemical analysis of foods. (7th ed.). London: J. and A. Churchill.

Pratt, E. L. and Snyderman, S.E. (1953). Renal water requirement of infants fed evaporated milk with and without added carbohydrate. Pediatrics, 11 (1), $65-69$.

PubChem and the American Chemical Society (2018). Reshaping Scholarly Communication. USA: University of California, 2005 - 05-31. Retrieved 2018- $10-15$.

Sengev, I.A., and Nwobi, I.S. (2016). Effect of crayfish inclusion on the chemical and sensory properties of ogi prepared from maize, millet and sorghum. International Journal of Nutrition and Food Science, 5(6), 378 - 383.

Snively, W.D. Jr., and Wessener, M. (1954). The ABCs, of fluid balance. Journal of Indiana State Medical Association, 47(9), 957 - 972.

Varian, T. (1975). Basic Atomic Absorption Spectroscopy: a modern introduction. Springvale, Australia: Varian, Techtron Pty Ltd.

Watts, D.L (2010). HTMA mineral ratios: A brief discussion of their clinical importance. Trace Elements Newsletter, 21(1), 1-3.

White House Conferences (1932). Growth and development of the child. New York: Appleton - Century - Crofts.

WHO (1999). Complementary feeding of young children in Africa and the Middle East. Geneva, Switzerland: WHO.

Zhang, G., Xu, Z., Gao, Y., Huang, X., and Yang, T. (2015). Effects of germination on the nutritional properties, phenolic profiles and antioxidant activities of buckwheat. Journal of Food Science, 80, H1111 - H 1119. 